International Journal of Instruction e-ISSN: 1308-1470 • www.e-iji.net

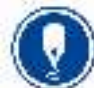

July $2021 \bullet$ Vol.14, No.3

p-ISSN: 1694-609X

pp. 705-716

Article submission code

20200820053955
Received: 20/08/2020

Revision: 16/01/202
Accepted: 09/02/2021

OnlineFirst: 10/06/2021

\title{
The Availability of Problem-solving Skills among Gifted Students in Schools of Excellence and its Relation with their Parents' Academic Level
}

\section{Mahmoud Ghazi Ewies}

Post-graduate student, Universiti Sains Malaysia, School of Education, Special Education Department, Malaysia, ewies71@ @otmail.com

\section{Aznan Che Ahmad}

Assoc. Prof., corresponding author, Special Education, School of Educational Studies Universiti Sains Malaysia 11800 USM, Penang, Malaysia, drnan6873@gmail.com

\section{Aswati Hamzah}

Assoc. Prof., Special Education, School of Educational Studies Universiti Sains Malaysia 11800 USM, Penang, Malaysia, aswati@usm.my

Modern societies face problems due to rapid, multiple, and continuous changes; this has led to the necessity for individuals in the twenty-first century to possess the skills to solve problems. Perhaps the most important groups of society which shape the future of any community are gifted students. Therefore, this study seeks to bridge the knowledge gap related to examine the level of solving-problem skills for gifted students in King Abdullah II Schools for Excellence and determine whether there is any effect of parents' academic level on problem-solving skills among the gifted students. The study used the descriptive and analytical method to achieve the objectives. The research population consists of 206 participants; the research sample reached 80 respondents chosen as a stratified random sample. To achieve the research goals, the researchers used the Heppner assessment to solve problems. The validity and reliability of the instrument were verified. SPSS program used to reach the results, descriptive statistics were used; also, the ANOVA test was used to determine the effect of demographic characteristics. The study results found that $66 \%$ of gifted students were below the acceptable level in the ability to solve problems, while $34 \%$ were within the acceptable level. The findings also showed no statistically significant differences attributed to the gifted student's father's and mother's academic level on the ability to solve the problem. The researchers made recommendations regarding training gifted students, their teachers, and their parents in problem-solving skills based on the study results.

Keywords: solving-problem, heppner assessment, gifted student, excellence schools in jordan (kase), demographic characteristics

Citation: Ewies, M.G., Ahmad, A. C., \& Hamzah, A. (2021). The availability of problem-solving skills among gifted students in schools of excellence and its relation with their parents' academic level. International Journal of Instruction, 14(3), 705-716. https://doi.org/10.29333/iji.2021.14341a 


\section{INTRODUCTION}

The ultimate goal of any educational system is the student's ability to solve life problems he/she encounters in creative ways (Abu-Jado \& Nofal, 2007; Ayasrah, 2013). It is a natural thing that our students face problems in their daily lives, due to the technological development and scientific progress which accelerating amazingly. This unique technology has resulted in many ethical, economic, and social problems that must be faced (Ateyya, 2008). And if it is necessary to train all students on the skills of the ability to solve problems to face these problems, then preparing gifted students can never be ignored because of their role in building and developing their societies in the future. Qatami (2004) defined the problem as the feeling that there is a difficulty that must be overcome to achieve a goal. In the same context, Groh and Allen (2001) define problem-solving skills as a process that motivates students to use their experiences and apply them to solve problems they collectively face, which helps them retain what they have learned.

Consequently, the ability to solve problems is closely related to the educational process, as it shows the extent to which an individual uses his/her intelligence to face a series of problems that he/she faces in his/her life and tries to overcome them (Al-Zgoul \& AlZgoul, 2003). Also, problem-based learning motivates students to confront the problems they encounter in creative ways (Al-Mansour, 2007).

On the other hand, Farahat (2015) indicated that providing students with the skills to solve problems leads to developing their affiliation with their religion and homeland, increasing students' self-reliance, increasing confidence in their abilities, and respecting themselves. Besides, Zaytoun (2004) added that the problem-solving strategy's advantages go beyond the student's aspects to affect the educational process. In this strategy, there is a goal for the student who seeks to achieve it to reach an innovative solution to the problem; this solution makes education meaningful to the teaching of the student because it connects between what he/she learns and what he/she applies in his real life.

In line with what was presented in the introduction regarding the definition of problemsolving skills and its importance for students in general, for gifted students in particular, and society, this research paper seeks to determine the problem-solving skills among gifted students at King Abdullah II School for Excellence. These students are selected with particular criteria set by the Ministry of Education, including tests and interviews, to measure their skills. Therefore, this study seeks to explore the extent to which students affiliated with King Abdullah II schools possess excellence in problem-solving skills using the Heppner test, and study the effect of some demographic characteristics such as the father's educational level and the academic level of the mother in the skills of ability to solve problems among gifted students.

The study seeks to achieve the following objectives:

i. To examine the level of solving-problem skills for gifted students in (KASE).

ii. To examine whether there is any effect of father's education on problem-solving skills among the gifted students. 
iii. To examine whether there is any effect of mother's education on problem-solving skills among the gifted students.

\section{Literature Review}

Few studies were conducted to check the extent to which gifted students possess problem-solving skills. One of these studies is Dreeb (2014) study, which aimed at comparing the capabilities of ordinary and gifted students in creative thinking and problem-solving skill. The study sample was (240) students from the fifth preparatory grade of regular and gifted students. The sample was classified into ordinary and gifted according to schools to which they belong; the researcher used a side thinking test and a measure of problem-solving skills. Study results showed that the level of ability to solve problems among gifted students was moderate. This result agreed with a study conducted by Al-Fasatlah (2015) on gifted students from King Abdullah II School of Excellence in Jordan to know the gifted students' level in problem-solving skills. The research results showed that their skills in solving problems are at an average level. This level is not appropriate for the capabilities of gifted students. In the same context, these studies' result is consistent with Ucar, Ucar, and Çaliskan (2017), aiming to explore the level of students' skills in problem-solving. The results indicated that the level of gifted students' problem-solving skills was not high.

King Abdullah II Schools of Excellence (KASE) guarantee the necessity of having activities concerned with developing thinking and creativity among students in all fields, besides the Ministry's formal curricula. The activities include enrichment programs scheduled for students in these schools from the seventh to the eleventh grade in mathematics and information technology and Electronics and leadership education. These programs are concerned with developing thinking and creativity among students in all fields (Ministry of Education, 2019).

Through a review of the theoretical literature, it appears clear that few studies measure the level of the ability to solve problem skills among gifted students. With several initiatives being implemented in King Abdullah schools of excellence to improve the twenty-first-century skills and interest in learning. The researchers want to ensure the level of gifted students is for these skills and whether there is a connection between specific demographic characteristics on improving problem-solving skills among gifted students.

This study comes to explore the extent of the ability of gifted students to solve problems in Jordan. It also shows the effect of the father and mother's educational level on solving problem skills among gifted students.

The importance of this study confirms that there is a contradiction in the results of previous studies about the level of gifted students in the ability to solve problems; The results of the Abuzaitoun and Banat (2010) study showed that gifted students possess a high level of these abilities, while the results of the study of Al-Fasatlah (2015), Dreeb (2014) and Ucar et al. (2017) contradicted with it. In the same context, the lecture review showed a contradiction in the results of the impact of some demographic characteristics in developing the ability to solve problems such as the father and 
mother's educational level. In the study of Arafah (2014) and Kaus et al. (2017), the results showed a statistically significant effect related to the academic level of the parents. According to these studies, children who live in an academic environment have higher problem-solving skills than children from a poorly educated environment. Parents' educational level makes them more interested in their children's abilities and keener to develop their skills by providing aids such as the home library and educational programs. On the other hand, the results of Tösten, Han, and Anik (2017) study indicated that the prediction of parents' influence in the ability to solve problem skills among their children does not exceed $20 \%$. This result was supported by Çağlayan (2008) study, which concluded that there is no statistically significant effect attributed to the parents' educational level.

This study will seek to explain these contradictions and determine the position of gifted students in Jordan from these results. Researchers believe that this study will benefit officials and decision-makers in building treatment plans to avoid the risks of students' weakness in solving problems. These skills are necessary for gifted students.

This research will also give the teachers a clear perception of their students' level in these skills; this calls for increased attention to essential skills for students and enriching gifted students with these skills. This study also opens the way for researchers to develop treatment plans, the Individualized Education Plans (IEP), ALP (Advanced Learning Plans), and training programs to develop these skills.

This research paper relies on the growing interest in developing twenty-first-century skills and enabling students and gifted students in particular to possess thinking skills and the ability to solve problems in creative ways. This enabling will not happen without knowing the level of this category's ability to solve problems. The results also benefit the officials, educational supervisors, teachers, and students themselves; as it puts in front of them a clear picture of their ability to solve problems, which opens the way for researchers to design enrichment and training programs to develop the skills of this important category in society.

By reviewing the previous literature and the objectives of this study, this study's importance is evident as it will clarify the level of gifted students in King Abdullah II Schools for excellence in problem-solving skills. Within the limits of the researcher's knowledge, no research has been conducted to study the effect of demographic characteristics (fathers and mothers' academic level) on these skills among gifted students in Jordan.

Many theories have emerged that show the family's effect on children in many fields (Newman \& Newman, 2011). Besides, many studies have shown that parents affect their children's ability to solve problems, such as studies (Arafah, 2014; Kaus et al., 2017; Sungur \& Bal, 2016).

These studies are based on the idea that educated parents provide a supportive environment for their children to develop their abilities and provide multiple learning resources such as libraries, films, and numerous electronic resources. In the same context, educated parents use more democratic methods in dealing with children, which develops their ability to solve problems and make decisions. 
The researchers test the following two hypotheses:

H1: There is an effect of father's education on problem-solving skills among the gifted students.

$\mathrm{H} 2$ : There is an effect of mother's education on problem-solving skills among the gifted students.

That research paper includes the following terms:

\section{Gifted Students}

Reis and Renzulli (2004) defined gifted students as students who outperform his/her peers in one or more fields of what is considered valuable in a community. Gifted students are a useful resource for leading societies; they are the nation's future and destiny (Al-Qummash \& Al-Maaytah, 2014). Therefore, countries have sought to discover them and offer all programs compatible with their needs to make the most of their capabilities (Al-Tabeeb \& Al-Malool, 2016).

\section{(KASE) Schools}

Jordan is the first country in the Middle East that has realized the importance of discovering and caring for the gifted, providing them with programs that suit their needs since the eighties of the last century (Al-Suroor; Nadia, 2003). Many programs have been established to support and care for the gifted, such as acceleration program, grouping, and enrichment (Ministry of Education, 2015). (KASE) schools are one of these programs, which receive gifted students under special conditions and tests. KASE is an acronym for King Abdullah II Schools for Excellence.

\section{Heppner Problem-Solving Skills Scale}

A measure of the ability to solve problems, Designed by Heppner, the scale consisting of forty items divided into five problem-solving skills, the answer is within the four Lekart levels. The Heppner scale was used to solve problems in many Arabs and international studies because of its sincerity and reliability, so Hamdi (1998) Arabized the scale and adapted it with the Jordanian environment; his study showed validity and reliability of the test.

\section{Problem-Solving}

A complex thinking process in which an individual uses his/her experience and skills to perform unfamiliar tasks or address the problem that he/she doesn't know how to solve to achieve a goal (Jarwan \& Al-Abbadi, 2014).

Hokanson (2017) mentioned that one of the essential skills needed in the twenty-first century is creative problem solving because the problems are varied and will not end. The development of the student's abilities to solve problems helps increase the students' self-confidence and improve their social relations with their colleagues, enhancing their scientific performance and developing social and intellectual skills (Daunic, Smith, Robinson, \& Landry, 2000). 


\section{METHOD}

The study used the descriptive and analytical method to identify the extent of the gifted students in Jordan can solve problems and study the effect of father and mother's educational level on these abilities.

\section{Participants}

The study population consisted of 206 students who were all the students of the seventh, eighth and ninth grades in the King Abdullah II School of Excellence (KASE) in Madaba and enrolled in the first semester in 2019/2020. The study sample consisted of 80 (KASE) students. The researcher chose the stratified random sample, which is considered the best and most accurate sample in representing the statistical community (Mukhtar, 2016). Therefore, three layers representing the seventh, eighth, and ninth grades were identified, and the total number of students in each layer was determined. Calculations were made to determine the number of students that corresponds to their proportions in a study population. The number of students per class was calculated according to an equation based on students' percentage in each layer of the sample levels.

The formula used: $\left(\mathrm{n}^{*} \mathrm{~N}^{1 /} \mathrm{N}\right)$ (Rekan, 2007). Where $(\mathrm{n})=$ the sample size. $\left(\mathrm{N}^{1}\right)=$ the number of students in the grade. $(\mathrm{N})=$ the population. In this study, $\mathrm{n}=80$ student refers to the sample of the study. $\mathrm{N}^{1}=80$ student for grade nine. $\mathrm{N}^{2}=80$ student for grade eight. $\mathrm{N}^{3}=46$ student for grade seven. $\mathrm{N}=206$. Table 1 shows the sample distribution. Accordingly, the researcher randomly selected twenty students from the seventh grade, thirty students from the eighth grade, and thirty students from the ninth grade.

Table 1

Number of students from each grade in each group

\begin{tabular}{lll}
\hline Grade & Number of the students & Number of samples \\
\hline Nine & $\mathrm{N}^{1}=80$ & $\mathrm{n}=80 * 80 / 206=31$ \\
\hline Eight & $\mathrm{N}^{2}=80$ & $\mathrm{n}=80 * 80 / 206=31$ \\
\hline Seven & $\mathrm{N}^{3}=46$ & $\mathrm{n}=80 * 46 / 206=18$ \\
\hline
\end{tabular}

After determining the numbers required from each class (seventh, eighth, ninth), all students' names in each level separately were put in containers, and the wanted number of participants from each stage was randomly selected.

\section{Data Analysis}

Descriptive statistics were used as the mean and standard deviation to answer the first question in the paper. The study also used SPSS version 25 to achieve the second and third objectives by using the ANOVA test to study whether there was an effect of the father and mother's educational level in solving problems skills among gifted students in Jordan (KASE) schools. 


\section{Instrument}

To achieve the objectives of the research, which is to determine the level of gifted students in (KASE) in the ability to solve problems, the researchers used Heppner Test, which was modified by Hamdi (1998) to suit the Jordanian environment; the test consists of five sub-skills, each includes eight statements. The five skills are Identifying the problem, generating alternatives, Making a decision, Assessment, and General attitude. The instrument was presented to ten arbitrators from university professors, university teachers, educational supervisors, educational psychology, and teachers to ensure reliability and validity, pumping $85 \%$ of them agreed to test items. The correlation coefficient between fields was calculated according to the Alpha Cronbach equation; it was (.86), suitable for the study. Cronbach alpha test was computed for all dimensions; its value was between (0.76-0.81).

\section{FINDINGS}

The study results will be reviewed according to the objectives and questions that the research paper answers.

\section{The first question in the research}

What is the level of solving-problem skills for gifted students in (KASE)?

After correcting the test, according to Heppner's correction guide, the researchers reached the study question results. The students were classified according to the correction guide to their ability to solve problems. The arithmetic averages were used to determine the percentage of students in each category (Figure 1).

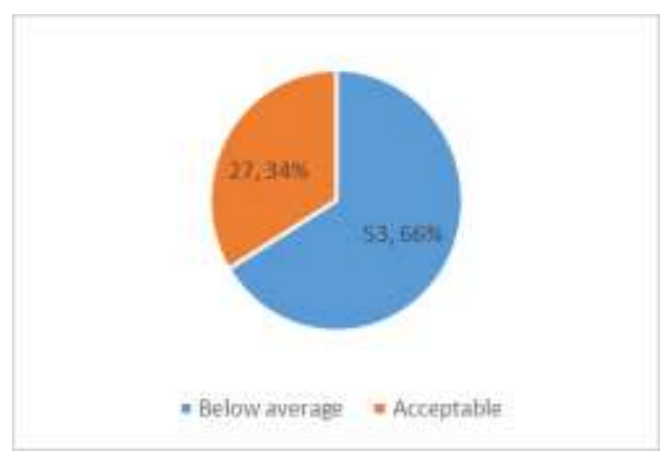

Figure 1

Percentage of students according to their ability to solve problems.

Figure 1 shows the percentage of gifted students with good problem-solving skills, which is $(34 \%)$ of the sample. This result does not match the assumed capabilities of this distinguished group of students.

The ANOVA test results also showed no statistically significant differences in the fivedimensional averages of students performing the test (Table2). 
Table 2

The comparison between the (HTSP) dimensions means using the ANOVA test.

\begin{tabular}{lrrrr}
\hline Skills & Mean & $( \pm \mathrm{SD})$ & F value & $p$-value \\
\hline General Attitude & 15.02 & 1.70 & .449 & .773 \\
\hline Outlining the Problem & 15.05 & 1.66 & & \\
\hline Construction alternatives & 15.37 & 1.93 & & \\
\hline Making Decisions & 15.17 & 1.88 & & \\
\hline Assessment & 15.8 & 2.22 & & \\
\hline
\end{tabular}

The results of the ANOVA test, in table 2, show that there are no statistically significant differences between the five test dimensions averages since the $P$-value is higher than (.05) the level of significance.

\section{The second question in the research}

Is there any effect of father's education on problem-solving skills among the gifted students?

The ANOVA test was used to answer this question.

Table 2

Relationship between Father's academic level and the overall score of Heppner test for solving-problem skills using ANOVA test.

\begin{tabular}{llllll}
\hline Abilities & Fathers Education & Mean & $( \pm$ SD $)$ & F value & $p$-value \\
\hline \multirow{3}{*}{$\begin{array}{l}\text { Solving } \\
\text { problem } \\
\text { skills }\end{array}$} & Secondary or less & 75.11 & 3.87 & 2.48 & .067 \\
\cline { 2 - 6 } & Diploma & 78.78 & 3.49 & & \\
\cline { 2 - 7 } & Bachelor's degree & 77.12 & 3.60 & & \\
\cline { 2 - 6 } & Postgraduate & 76.93 & 4.41 & & \\
\hline
\end{tabular}

Discuss the Hypotheses one

$H_{1}$ : There is an effect of father's education on problem-solving skills among the gifted students.

This hypothesis was rejected; Table (3) shows no effect of the father's educational level on the ability to solve problems among gifted students in (KASE) schools. The $p$-value is (.067), which is higher than (.05), which means there is no effect of this demographic characteristic on solving problems skills.

\section{The third question in the research}

Is there is any effect of mother's education on problem-solving skills among the gifted students?

The ANOVA test was used to answer this question.

Table 3

Relationship between a mother's academic level and the Heppner test's overall score for solving-problem skills using ANOVA test.

\begin{tabular}{llllll}
\hline Abilities & Mothers Education & Mean & $( \pm$ SD) & F value & p-value \\
\hline \multirow{3}{*}{$\begin{array}{l}\text { Solving } \\
\text { problem skills }\end{array}$} & Secondary or less & 78.20 & 4.07 & .73 & .54 \\
\cline { 2 - 6 } & Diploma & 75.83 & 4.57 & & \\
\cline { 2 - 6 } & Bachelor's degree & 76.73 & 4.14 & & \\
\cline { 2 - 6 } & Postgraduate & 77.33 & 2.80 & & \\
\hline
\end{tabular}


Discuss the Hypotheses two

$\mathrm{H}_{2}$ : $\quad$ There is an effect of mother's education on problem-solving skills among the gifted students.

This hypothesis was rejected; Table (4) shows no effect of the mother's educational level on the ability to solve problems among gifted students in (KASE) schools. The p-value is (.54), which is higher than (.05) the level of significance. That means there is no effect of this demographic characteristic on the ability to solve problems.

\section{DISCUSSION}

The findings of the research paper will be discussed In line with the aims the research seeks to achieve as follow:

\section{Discussion of The first question in the research}

What is the level of solving-problem skills for gifted students in (KASE)?

The study results showed that the percentage of gifted students in King Abdullah Schools of Excellence in Madaba who achieved an acceptable level of problem-solving ability is $34 \%$ (Figure 1). The results also showed no statistically significant differences between the total score to solve problems test and the sub-skills.

This study's results agree with Dreeb (2014) research and Al-Fasatlah (2015) and Ucar et al., (2017 study), as the results show that the ability to solve problems among gifted students is average or less. We can justify this result because teachers focus more on knowledge than mental skills. In contrast, the teacher's focus is on the cognitive aspect, completing the curriculum, and keenness to obtain high school test marks. This justification corresponds to what was confirmed by Ayasreh and El-Omari (2016).

On the other hand, the study results differed from Abuzaitoun and Banat (2010) study, where gifted students' level was high in solving problems. The difference in the results of studies may be due to the sample's difference and its size.

\section{Discussion of The second question in the research}

Is there any effect of father's education on problem-solving skills among the gifted students?

The results showed no statistically significant differences attributed to the father's educational level (Table 3). The results also showed no statistically significant differences between the test's total score to solve problems and its sub-skills. (Table 4)

This study's results are consistent with Tösten, Han, and Anik (2017) research. Their study results showed that the degree of prediction of parents' effect on problem-solving abilities does not exceed $20 \%$. Also, the result of the current study consistent with Çağlayan (2008) study. On the other hand, the present study results differ from the study results of Arafah (2014) and Kaus et al. (2017), which showed an effect of the father's educational level on children's problem-solving ability.

Researchers justify the absence of an impact of the educational level on the ability to solve the problem among gifted students in Madaba, maybe because of educated parents' 
work and economic pressures on uneducated parents. Besides, the ability to solve problems is a skill that parents may not have because most of their interest is in their kids' achievement tests. Parents are not interested in thinking skills and what is associated with them, such as solving problems. These reasons lead to the absence of academic level in gifted students' skills to solve problems.

\section{Discussion of The third question in the research}

The current study results are consistent with Korkut (2002) study, which aimed to explore high school students' problem-solving skills in Turkey. On the other hand, The results of the current study differ from the results of the study of Sungur and Bal (2016); This difference is explained by the difference in the study sample, study procedures, and tools used in the studies.

Although mothers take care of their children, the mother's going out to reduce the husband's economic burden reduces the educated mother's chances of affecting her children. Besides, imparting problem-solving skills requires a mother to have these skills. Mothers' attention is also focused on the academic achievement of their children.

\section{CONCLUSION}

The study aimed to explore the extent to which gifted students in (KASE) schools possess the ability to solve problems and whether fathers' and mothers' qualifications impact these skills. According to the correction guide for the problem-solving ability test, the study results found that the level of gifted students in (KASE) schools is less than acceptable. The statistical test (ANOVA) also showed no statistically significant differences due to the academic level, whether for father or mother.

The study findings open the way for researchers in giftedness and creativity to build specialized programs to improve gifted students' abilities in solving problems. It also opens the doors to study other variables that may impact developing the ability to solve problems such as the family's economic level, the number of family members, birth order of the gifted, and age. Besides, this research paper will help decision-makers choose the best programs that might help the gifted in increasing problem-solving skills. This study is limited to knowing students' abilities in skills: Assessment, Identification of the problem, Generating alternatives, Making a decision, and General attitude. The study is also limited to the small sample and the choice of one school in Jordan; the study sample consists of gifted male students in grades seven, eight, and nine. Who affiliated to King Abdullah II Schools of Excellence in Madaba Governorate in the first semester of the academic year 2019-2020, using the study instrument, the Heppner assessment of the ability to solve problems.

The authors recommended that teachers pay attention to developing the ability to solve problems by giving them high importance.

Moreover, the researchers recommended designing specialized training programs to focus on developing the ability to solve problems to hone gifted students' skills, develop them, and meet their needs. Besides, it is necessary to provide training related to improving the ability to solve problems for teachers working in specially gifted schools and those working in traditional schools to deal professionally with gifted students. 
Finally, there is an urgent need for parents to participate in specialized programs in developing the skills of the twenty-first century and the ability to solve problems, in particular, to be able to support the school environment in stimulating creativity.

\section{REFERENCES}

Abu-Jado, S., \& Nofal, M. (2007). Teaching Thinking, Theory, and Implication (1st ed.). Amman: Dar Almaseerah.

Abuzaitoun, J., \& Banat, S. (2010). The Relationship Between Psychological Adjustment and Problem-Solving Among Gifted and Talented Students. Journal of Educational and Psychological Sciences, 11(2), 39-64.

Al-Fasatlah, R. (2015). Habits of Mind and its Relationship to the Ability to Solve problems among High Achievers Students in King Abdullah II Schools for Excellence schools in the Hashemite Kingdom of Jordan. Mutah.

Al-Mansour, G. (2007). Pedagogy Problem Solving. Damascus University Journal, 23(1), 417-452.

Al-Qummash, M., \& Al-Maaytah, K. (2014). Psychology of children with special needs (2nd ed.). Amman: Dar Almaseerah.

Al-Suroor; Nadia. (2003). Introduction to the Education of the Talented and Gifted (4th ed.). Amman: Dar El Fikr for Printing and Publishing.

Al-Tabeeb, M., \& Al-Malool, M. (2016). Libyan experience in the care of gifted. University Journal, 3(18), 51-76.

Al-Zgoul, R., \& Al-Zgoul, E. (2003). Cognitive Psychology (2nd ed.). Amman: Dar al Shorouq for Publication and Distribution.

Arafah, S. (2014). Relationship Between Ego Strength and Problem-solving Skills among the students of primary High Schools in Gaza. Gaza Islamic University.

Ateyya, M. (2008). Modern Curricula and Teaching Methods (1st ed.). Amman: Dar Almanahej.

Ayasrah, W. (2013). Creative Thinking Abilities and Solving-Problem Skills (1st ed.). Amman: dar Osamah.

Ayasreh, M., \& El-Omari, A. (2016). Problems of Gifted Students at King Abdullah II Schools for Excellence: Students Perspective. International Journal of Education and Practice 2016, 4(2), 55-70.

Çağlayan HS. (2008). Spor Yapan Lise Öğrencilerinin Problem Çözme Becerilerinin Çeşitli Değişkenler Açısından İncelenmesi. Niğde Üniversitesi Beden Eğitimi ve Spor Bilimleri Dergisi, 2(1), 62-77.

Daunic, A., Smith, S., Robinson, T., \& Landry, K. (2000). School-wide conflict resolution and peer mediation programs: Experiences in three middle schools. Intervention in School and Clinic, 36(1), 94-110.

Dreeb, M. (2014). Lateral Thinking and Problem-Solving Skills for Gifted and Ordinary Students. Kufa Studies Center Journal, 1(34), 308-381. 
Farahat, B. (2015). The Relationship of Thinking Methods to the Ability to Solve Problems in a Sample of Second Secondary Students - a Study in the State of Mesila -. Kasdi Merbah Warqalah University.

Hokanson, B. (2017). Developing Creative Thinking Skills (1st ed.). New York: Routledge.

Jarwan, F., \& Al-Abbadi, Z. (2014). The Impact of an Educational Program Based on Creative Problem-solving Strategy in Developing Creative Thinking Skills of Gifted Students with Learning Disabilities. Journal of the Union of Arab Universities for Education and Psychology, 12(1), 11-43.

Kaus, M. A., Ali, M. B., Halim, N. D. A., Phang, F. A., Samah, N. A., \& Ismail, A. K. (2017). The roles of parents in their children's physics problem-solving ability. Advanced Science Letters, 23(8), 7517-7520. https://doi.org/10.1166/asl.2017.9512

Ministry of Education. (2015). The Education Development Conference (p. 69). Amman: Ministry of Education. Retrieved from http://www.moe.gov.jo/ar/node/6512

Ministry of Education. (2019). http://www.moe.gov.jo/ar/node/7483.

Mukhtar, H. (2016). The Creative Thinking and its Relationship to the ability to Solving the Problems of Students of Talent and Excellence Schools Khartoum State-secondary Level. Sudan University of Science and Technology.

Newman, B. M., \& Newman, P. R. (2011). Adolescence, Theories of. In Encyclopedia of Adolescence (Vol. 1, pp. 20-29). Elsevier Inc. https://doi.org/10.1016/B978-0-12373951-3.00003-X

Qatami, N. (2004). Teaching Thinking for Elementry Stage. Amman: Dar El Fikr For Printing \& Publishing.

Reis, S., \& Renzulli, J. (2004). Current Research on Social and Emotional Development of Gifted and Talented Students: Good News and Future Possibilities. Psychology in the Schools, 41(1), 119-130.

Rekan, A. (2007). Estimating the population variance and estimating the size of the stratified random sample. Iraqi Journal of Statistical Sciences, 12(1), 229-244.

Sungur, G., \& Bal, P. N. (2016). Analysis of 4th Grade Students ' Problem-Solving Skills in Terms of Several Variables. Journal of Education and Practice, 7(14), 1-9.

Tösten, R., Han, B., \& Anik, S. (2017). The Impact of Parental Attitudes on Problem Solving Skills in High School Students. Universal Journal of Educational Research, 5(1), 170-174. https://doi.org/10.13189/ujer.2017.050121

Ucar, M., Ucar, M., \& Çaliskan, M. (2017). Investigation of Gifted Students’ ProblemSolving Skills. Journal for the Education of Gifted Young, 5(3), 1-14.

Zaytoun, A. (2004). Methods of Teaching Science (1st ed.). Amman: Dar al Shorouq for Publication and Distribution. 